\title{
References
}

Bridgwater, D., Davies, F. B., Gill, R. C. O., Gorman, B. E., Henriksen, N. \& Watterson, J. 1977: Field mapping in the Nagssugtoqidian of South-East Greenland. Rapp. Grønlands geol. Unders. 85, 74-83.

Bridgwater, D., Davies, F. B., Gill, R. C. O., Gorman, B. E., Myers, J. S., Pedersen, S. \& Taylor, P. 1978: Precambrian and Tertiary geology between Kangerdlugssuaq and Angmagssalik, south-eastern Greenland. Rapp. Grønlands geol. Unders. 83, 17 pp.

Wager, L. R. 1934: Geological investigations in East Greenland, Part 1. General geology from Angmagsalik to Kap Dalton. Meddr Grønland 105,2, 46 pp.

F.B.D.,

5 Silver Street,

Gastard,

Corsham Wilts,

U.K.

B.E.G.,

Department of Geology,

University of Western Ontario,

London, Ontario N6A 5B7,

Canada.
R.C.O.G. \& P.T., Department of Geology and Mineralogy, University of Oxford, Oxford $O X 13 P R$, U.K.

S.P., Institut for Petrologi, University of Copenhagen, $\emptyset$ ster Voldgade 10, 1350 Copenhagen $K$.

\section{Field work in uranium geology and prospecting, northern East Greenland}

\section{Agnete Steenfelt and Bjarne Leth Nielsen}

The field activity in 1977 completed a 5-year programme of exploration for uranium in northern East Greenland from $72^{\circ}$ to $76^{\circ} \mathrm{N}$ (Nielsen \& Larsen, 1974; Nielsen \& Steenfelt, 1975; Steenfelt, 1976). The following account refers to the field activities of 1976 and 1977.

As in previous years the group undertaking uranium geology and exploration was joined by small field teams working with various other geological subjects (see e.g. Hald, Thyrsted, this report), giving a total number of about 25 participants. All field teams were supported from the base camp in Stordal, Hudson Land (fig. 31).

The Stordal base camp is now dismantled and removed, except for the markings of the primitive runway which can still be used. During the field seasons the field teams and the prospecting work were served by a Bell 206B helicopter from Heliswiss, Bern.

Besides the authors the following persons participated in the exploration programme: $M$. Watt, W. Koensler, C. Cooper, T. Tukiainen, R. Johansson and a number of field assistants. The field activities in uranium exploration comprised:

(1) Follow-up of the aerial gamma-spectrometric survey of 1973 and 1974. 


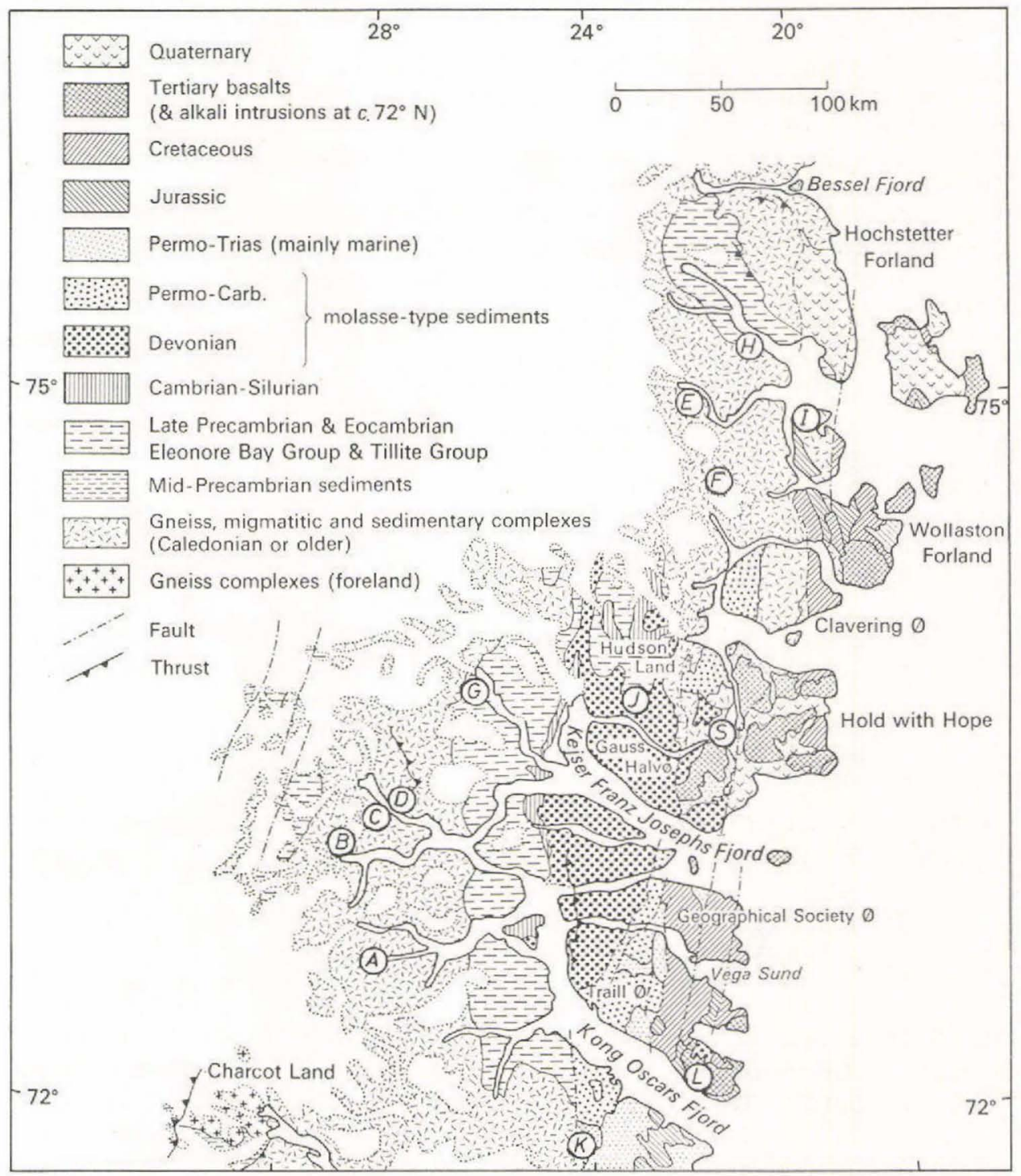

Fig. 31. Sketch map of northern East Greenland showing the areas investigated in detail during the uranium exploration programme 1976 and 1977. Metamorphic crystalline complex: head of Röhs Fjord (A), Knækdal (B), Haredal (C), Lacroix Bjerge (D), Birkedal (E), Vejstrups Dal (F); Eleonore Bay Group sediments: Dukkegletscher (G); Caledonian granites: Kildedal (H), Kuhn Ø (I); Devonian acid volcanics: Moskusokselandet (J); Tertiary intrusive complexes: Werner Bjerge (K), Kap Simpson (L). $(\mathrm{S})=$ Stordal base camp. 
(2) Completion of the geochemical sampling programme commenced in 1975 in Hudson Land and Gauss Halvø.

(3) Detailed field work in selected areas.

\section{Follow-up of aerial gamma-spectrometric survey}

Most of the anomalies obtained during the fixed-wing gamma-spectrometric survey have been checked. The areas of increased radioactivity were localised and measured with a total count scintillometer equipped with one $6 \times 4$ inches $\mathrm{NaI}(\mathrm{Tl})$ detector crystal installed in the helicopter. Geological description, sampling and ground scintillometry were subsequently made in each area.

In many places the anomalies could be explained by changes in lithology, e.g. by the occurrence of unmapped granites, and these areas warranted no further investigation. A few anomalies were never relocated in the field. The remaining anomalies demanded detailed field work in order to be fully understood.

\section{Geochemical prospecting programme}

This programme comprised sampling of stream sediments and stream water on a regional scale in Hudson Land and Gauss Halvø, and in detail in the major zone of faulting in eastern Hudson Land. A total of $c .2700$ stream sediment samples and $c .2300$ stream water samples have been taken and analysed for uranium at the Risø National Laboratory. In addition the stream sediments were analysed for $\mathrm{K}, \mathrm{Ca}, \mathrm{Ti}, \mathrm{V}, \mathrm{Cr}, \mathrm{Mn}, \mathrm{Fe}, \mathrm{Ni}, \mathrm{Cu}, \mathrm{Zn}, \mathrm{Ca}, \mathrm{Pb}, \mathrm{Sr}$. The results of the analyses and the field information are processed by computer and the uranium values are plotted on drainage system maps.

The main conclusion to be drawn at the present stage of the work is that both stream sediments and stream water reflect the bedrock geology of the drainage areas, and that they indicate uranium enrichment along the fault zone of eastern Hudson Land.

\section{Detailed field work}

The areas investigated in detail are indicated on fig. 31. A brief account of the areas studied by the authors is given below.

\section{Birkedal}

A scintillometric survey was carried out from helicopter on six anomalies discovered in Birkedal during the fixed-wing gamma-spectrometric survey, and the subsequent field work was concentrated in one of the anomalous areas.

The Birkedal area consists of a series of Precambrian metamorphic rocks, mainly gneisses and migmatites. The extent of the possible Caledonian reworking is not known in detail.

During the field scintillometric survey 'background' levels of radioactivity were recorded in biotite gneiss and garnet gneiss which are common rock types of the area. The radioactive anomalies were confined to a number of lithological environments within a banded gneiss 
series. These are (1) granitic and quartz-rich enclaves in the light coloured units of the banded gneiss, (2) biotite-rich banded gneiss, and (3) greenish pegmatitic streaky gneiss. The anomalies, which are numerous but of limited extent on the surface, are typically of 3 to 10 times background count rates. Uranium and thorium analyses have not yet been carried out.

Some of the local anomalies can be explained by the presence of radioactive accessory minerals like allanite and zircon. Further studies should none-the-less be devoted to the anomalies which cannot readily be explained and which might possess some ultimate economic importance.

\section{Kildedal}

Aerial gamma-anomalies were recorded in the Kildedal area which geologically belongs to the western part of the Caledonian Ardencaple Fjord Batholith. In the area investigated granites are emplaced almost concordantly along the bedding planes of quartz-rich sediments of the Eleonore Bay Group and their metamorphic equivalents. From the field work in the area it can be concluded that the main reason for the earlier observed anomalies is a strong radiometric contrast between sediments-metasediments and granites. Some characteristic variation is however observed between the various types of granites and the table below illustrates ranges of the count rates recorded with a SPP2 Saphymo Stel scintillometer from the main lithological units. There seems to be no economic uranium potential in the area.

$\begin{array}{lc}\text { Rock type } & \text { Count rate (cps) } \\ \text { Quartzitic metasediment } & 100-150 \\ \text { Schist } & 100-150 \\ \text { Biotite granite } & 200-300 \\ \text { Muscovite granite } & 150-200 \\ \text { Porphyritic biotite granite } & 150-200\end{array}$

\section{Dukkegletscher}

The Dukkegletscher anomaly is one of a number of anomalies recorded in the Eleonore Bay Group sediments during the aerial surveys. Most of these anomalies are without further interest as they are associated with 50 to $100 \mathrm{~m}$ thick black bands of claystones and siltstone of units $5,6,7$ and 8 which radioactively contrast with the surrounding quartzites and limestones. The field work around Dukkegletscher was intended as a more detailed field documentation of the distribution of radioactive elements in part of the Eleonore Bay Group sediments. It was found that in general the content of radioactive elements is low in all rock types. No mineralisation was encountered and it is concluded that the Eleonore Bay Group sediments are unfavourable for further uranium prospecting.

\section{Kuhn Ø}

An area in the north-western part of Kuhn $\varnothing$ was investigated in detail because sediments from a stream draining a glacier-filled corrie had a uranium content in the range of 30-60 
ppm (5-10 times the background). The rocks represented in this area are Eleonore Bay Group sediments of units 5 and 6 and Caledonian granites. The slightly metamorphosed sediments occur as a NW-SE trending belt in fault contact with granite on the north-eastern side and intruded by granite along the south-western side. The fault intersects the corrie.

The entire frontal blocky moraine was surveyed systematically by scintillometer and traverses were made in the surroundings of the glacier, particularly along contacts and granite apophyses. However, the results from this work were all negative and the stream sediment anomaly remains unexplained.

\section{Moskusokselandet}

The considerable amount of acid volcanic rock discovered in this part of Hudson Land in 1975 (Steenfelt, 1976) has since been surveyed by helicopter-borne scintillometer and has been the object of several field visits. A stream sediment uranium anomaly ( $37 \mathrm{ppm} \mathrm{U}$ ) in the area led to the discovery of a new small mineralisation similar to those occurring near Hochwacht $5 \mathrm{~km}$ to the east (Steenfelt, 1976). The host rock is a dense red rhyolite in which pitchblende and carburan have been found disseminated and in veinlets. This is the first occurrence of pitchblende in Greenland. The uranium content of mineralised rock samples is of the order of $4000 \mathrm{ppm}$.

\section{The major fault zone in eastern Hudson Land}

Detailed mapping, rock sampling and scintillometry were performed in the fault zone in order to further delineate and explain the anomalies recorded by the aerial survey and geochemical prospecting. Most of the anomalies proved to be related to granites which have higher background contents of uranium and locally contain uraniferous hematite on joint surfaces. Important mineralisation was not found during the work and the material collected is now being analysed for further evaluation.

\section{Werner Bjerge and Kap Simpson}

Groups of anomalies from the aerial survey are located within the Tertiary alkaline complexes of Werner Bjerge and Kap Simpson. The complexes consist of extrusive and intrusive rocks dominated by quartz-rich porphyries, syenites and granites. Most of the complexes have been surveyed by helicopter and detailed field work was carried out in selected areas.

At southern Werner Bjerge increased radioactivity was detected in a few joint zones and in small fluorite-calcite veins in acid porphyritic rocks.

Within the Kap Simpson complex uranium mineralisation was discovered in a late intrusive granite with a relatively high background radioactivity. The granite is fine to medium grained and commonly very fractured. The fracture surfaces are characteristically coated in black.

Many 'hot spots' were detected in joints in the 'black' granite, and more field work is advocated to establish the extent and amount of mineralisation in the area. 
Another group of anomalies in the Kap Simpson complex was investigated and proved to be caused by a dark acid lava with slightly increased radioactivity.

Both intrusive complexes are rich in sulphides and pneumatolytic to hydrothermal activity has created spectacularly coloured zones of alteration. None of these zones showed increased radioactivity.

\section{References}

Nielsen, B. L. \& Larsen, H. C. 1974: Airborne geophysical survey in central East Greenland. Rapp. Grønlands geol. Unders. 65, 73-76.

Nielsen, B. L. \& Steenfelt, A. 1975: Prospecting for uranium in central East Greenland. Rapp. Grønlands geol. Unders. 75, 107-110.

Steenfelt, A. 1976: Uranium exploration in northern East Greenland. Rapp. Grønlands geol. Unders. 80, 110-112.

\section{Structural and metamorphic studies in the East Greenland Caledonides between $72^{\circ}$ and $74^{\circ} \mathrm{N}$}

\section{Tage Thyrsted}

In 1975 and 1976 investigations were carried out in the East Greenland Caledonides in the region between $72^{\circ}$ and $74^{\circ} \mathrm{N}$ with special reference to basement-cover relationships and regional metamorphic studies and backed up by isotopic studies (Friderichsen \& Higgins, 1976; Higgins et al., 1977).

In 1977 the work comprised mainly metamorphic investigations. Short descriptions of the localities visited are given below.

\section{Southern Louise Boyd Land}

A section was studied in an arid sandy valley ('Desert Valley', fig. 32) closely comparable to the Knækdal section to the south visited in 1976 (Higgins et al., 1977, p. 112). In the western two thirds of the valley the late Precambrian sediments of the Petermann Series are exposed, comprising from top to bottom the Summit 'series', the Layered 'series', the Phyllite 'series', and the Mystery Quartzite 'series'. The last-named is more completely represented in southern Louise Boyd Land than in Knækdal, attaining an estimated thickness of $3500 \mathrm{~m}$ (tectonic thickening cannot be excluded).

Underlying the Petermann Series a sequence of metasediments consists of about $700 \mathrm{~m}$ of rusty mica schist with numerous sheets of two-mica granite, and underlain by an almost $2 \mathrm{~km}$ thick unit of semipelitic to quartzitic schists. The boundary with the overlying series seems to be concordant. 